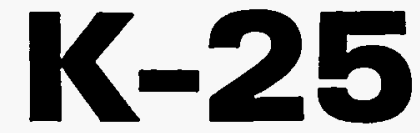

OAK RIDGE K-25 SITE

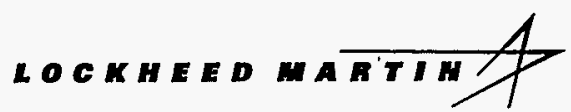

MANAGED BY

LOCKHEED MARTIN ENERGY SYSTEMS, INC.

FOR THE UNITED STATES

DEPARTMENT OF ENERGY
RECEIVED

NOV $0 ? 1996$

OSTI

$\therefore \therefore$

STANDARD PROCESS

for the

ROLES AND RESPONSWHITIES

FOR FACILITY REUSE OF

DOE OAK RDGE RESERVATION

FACILITIES
A. S. Loebl
D. G. Trost
J. A. Pastel
S. G. Payne
R. M. Fleenor

April 1996 


\section{DISCLAIMER}

This report was prepared as an account of work sponsored by an agency of the United States Government. Neither the United States Government nor any agency thereof, nor any of their employees, makes any warranty, express or implied, or assumes any legal liability or responsibility for the accuracy, completeness, or usefulness of any information, apparatus, product, or process disclosed, or represents that its use would not infringe privately owned rights. Reference herein to any specific commercial product, process, or service by trade name, trademark, manufacturer, or otherwise, does not necessarily constitute or imply its endorsement, recommendation, or favoring by the United States Government or any agency thereof. The views and opinions of authors expressed herein do not necessarily state or reflect those of the United States Government or any agency thereof.

This report has been reproduced directly from the best available copy.

Available to DOE and DOE contractors from the Office of Scientific and Technical Information, P. O. Box 62, Oak Ridge, TN 37831; prices available from 423-5768401.

Available to the public from the National Technical Information Service, U.S. Department of Commerce, 5285 Port Royal Rd., Springfield, VA 22161. 
E.

OAK RIDGE K-25 SITE

LOCKHEED WATRIN
RECEIVED

NOV 0 ? 1996

OSTI
STANDARD PROCESS

for the

\section{ROLES AND RESPONSIBILITIES}

FOR FACILITY REUSE OF

DOE OAK RIDGE RESERVATION

FACILITIES
A. S. Loebl
D. G. Trost
J. A. Pastel
S. G. Payne
R. M. Fleenor

April 1996 


\section{DISCLAIMER}

This report was prepared as an account of work sponsored by an agency of the United States Government. Neither the United States Government nor any agency thereof, nor any of their employees, makes any warranty, express or implied, or assumes any legal liability or responsibility for the accuracy, completeness, or usefulness of any information, apparatus, product, or process disclosed, or represents that its use would not infringe privately owned rights. Reference herein to any specific commercial product, process, or service by trade name, trademark, manufacturer, or otherwise, does not necessarily constitute or imply its endorsement, recommendation, or favoring by the United States Government or any agency thereof. The views and opinions of authors expressed herein do not necessarily state or reflect those of the United States Government or any agency thereof.

This report has been reproduced directly from the best available copy.

Available to DOE and DOE contractors from the Office of Scientific and Technical Information, P. O. Box 62, Oak Ridge, TN 37831; prices available from 423-5768401.

Available to the public from the National Technical Information Service, U.S. Department of Commerce, 5285 Port Royal Rd., Springfield, VA 22161. 


\title{
STANDARD PROCESS for the ROLES AND RESPONSIBILITIES FOR FACILITY REUSE OF DOE OAK RIDGE RESERVATION FACILITIES
}

\author{
A. S. Loebl \\ D. G. Trost* \\ J. A. Pastel* \\ S. G. Payne* \\ R. M. Fleenor \\ April 1996 \\ *Consultant with Science Applications International Corporation for \\ Finance and Business Management \\ Lockheed Martin Energy Systems, Oak Ridge K-25 Site \\ Oak Ridge, TN 37831
}

\author{
Prepared by the \\ OAK RIDGE K-25 SITE \\ Oak Ridge, Tennessee 37831 \\ managed by \\ LOCKHEED MARTIN ENERGY SYSTEMS \\ for the \\ U.S. DEPARTMENT OF ENERGY \\ under contract DE-AC05-840R21400
}




\section{DISCLAIMER}

Portions of this document may be illegible in electronic image products. Images are produced from the best available original document. 


\section{CONTENTS}

ABBREVIATIONS AND ACRONYMS $\ldots \ldots \ldots \ldots \ldots \ldots \ldots \ldots$ v

INTRODUCTION $\ldots \ldots \ldots \ldots \ldots \ldots \ldots \ldots \ldots \ldots \ldots \ldots \ldots \ldots \ldots$

I. REAL ESTATE IDENTIFICATION: CONTINUING ACTIVITY . . . 3

II. FACILITIES ANALYSIS: 86 DAYS $\ldots \ldots \ldots \ldots \ldots \ldots \ldots$

IIA. DOE Technical Review ................... 4

IIB. Tenant Technical Review: 30 Days ................ 5

IIC. Negotiate Modifications: 25 Days ............... 5

III. EQUIPMENT TRANSFERS: 38 DAYS $\ldots \ldots \ldots \ldots \ldots \ldots \ldots$

IV. NEPA ANALYSIS $\ldots \ldots \ldots \ldots \ldots \ldots \ldots \ldots \ldots \ldots \ldots \ldots \ldots \ldots \ldots$

IVA. Appendix A7 CX Determination: 2 Days $\ldots \ldots \ldots \ldots \ldots 7$

IVB. Proposed Appendix B 1.24 CX Determination: 11 Days . . . . . 8

IVC. Single Facility Environmental Assessment: 117 Days ...... 8

IVD. National Historic Preservation Act (NHPA) Process ....... 8

V. LEASE CONTRACT PREPARATION (Prime Lease): 33 DAYS .... 9

VI. FINAL OCCUPANCY $\ldots \ldots \ldots \ldots \ldots \ldots \ldots \ldots \ldots \ldots \ldots \ldots \ldots \ldots$

APPENDIX A FLOWCHART

APPENDIX B SHORTENING THE CRITICAL PATH 



\section{ABBREVIATIONS AND ACRONYMS}

ACHP Advisory Council on Historic Preservation

CROET Community Reuse Organization of East Tennessee

CX Categorical Exclusions

DOE Department of Energy

EA Environmental Analysis

EPA Environmental Protection Agency

LMES Lockheed Martin Energy Systems, Inc.

M\&O Managing \& Operating

MOA Memorandum of Agreement

NEPA National Environmental Policy Act

NHPA National Historic Preservation Act

ORNL Oak Ridge National Laboratory

ORO Oak Ridge Operations

ORR Oak Ridge Reservation

REAPS Reportable Excess Automated Property System

SHPO State Historic Preservation Officer 


\section{ROLES AND RESPONSIBILITIES FOR FACIIITY REUSE OF DOE OAK RIDGE RESERVATION FACILITIES}

\section{INTRODUCTION}

The purpose of this report is to provide an understanding of the standard process for the lease or sale of facilities, equipment, and real property for the Oak Ridge Reservation (ORR). The objective of this process is to facilitate the reindustrialization of the ORR for the Department of Energy (DOE). The roles and responsibilities in this standard, as defined in the attached narrative and flow diagrams, were agreed upon among various representatives from the DOE-Oak Ridge Operations Office (DOE-ORO), Lockheed Martin Energy Systems, Inc. (LMES), and the Community Reuse Organization of East Tennessee (CROET).

Reindustrialization for the DOE encompasses several areas which include: facilities reuse, materials and equipment recycling, and worker transition activities. The DOE-ORO's vision for the ORR is to have completed the reindustrialization activities for the K-25 Site by the year 2010 . Several steps have already been taken to aggressively pursue this vision, such as determining the most efficient and cost-effective ways to expedite the facilities reuse process. This report provides the time-phased, step-by-step, process for the lease or sale of facilities, equipment, land, and suggestions on streamlining the required regulatory processes.

Due to the possibility that stipulations in the National Environmental Policy Act (NEPA) could be invoked in three different ways, there are three separate potential processes for facilities reuse depicted in this report. The flowcharts for each process are provided in Appendix A. The three flowcharts provide critical path and Gantt depictions. The flowcharts reflect the steps involved in: 1) NEPA Environmental Assessment for a Single Facility (a 133-day process), 2) NEPA Appendix A7 Categorical Exclusion Is Applicable (a 103-day process), and 3) Appendix B 1.24 Categorical Exclusion Is Applicable (a 103-day process). Each process begins with the identification of real estate suitable for reuse and continues through the start of build-out (if any). However, it is important to note that the step-by-step process for each is slightly different. The narrative portion of this report has been provided in order to identify the step, duration, and the participant roles and responsibilities for the facility reuse process. Flowcharts which appear in Appendix A show the logic and time phasing.

Appendix B in this report is titled, "Shortening the Critical Path." This document provides an overview of how the entire process could be accomplished in fewer days. A K-25 Site-wide Programmatic Environmental Assessment for reuse has been commissioned by DOE-ORO. Once completed, the standard time required to execute the process will be shortened as well. Other suggestions for shortening the critical path are included in the process narrative. This report is intended to provide an understanding of the agreed-upon-standard for facilities reuse activities for the ORR. The attachments will provide the reader with a clear understanding of how this standard can be effectively and efficiently implemented. 
THIS PAGE IS INTENTIONALLY BLANK 
The following is an annotative narrative for the attached facility reuse process flowcharts. The narrative identifies Lockheed Martin Energy Systems (LMES), the Department of Energy-Oak Ridge (DOE-OR), and DOE Site Office roles and responsibilities in facility reuse at the Oak Ridge Reservation, including necessary interfaces with stakeholders of the East Tennessee Region, the Community Reuse Organization of East Tennessee (CROET) ${ }^{1}$, and the CROETidentified tenants. The narrative follows the flowchart. At appropriate points in the narrative, the advantages and time consequences of individual leases and environmental analyses are addressed. Additional information addressing alternative concepts is included in the attached document titled, "Shortening the Critical Path."

\section{REAL ESTATE IDENTIFICATION: CONTINUING ACTIVITY}

1. Identify real estate suitable for reuse: continuing: DOE-OR, DOE Site Office, LMES, CROET, Tenant.

DOE-OR, DOE Site Office, LMES, and the CROET, representing potential tenants, identify real estate suitable for reuse in a coordinated process. The identification process begins prior to the schedule and is continuing.

2. Requests space: 1 day: CROET

The CROET is responsible for identifying possible space with a real potential for occupancy and formally requesting the space from DOE. This action starts the process described in the flow chart.

\section{FACILITIES ANALYSIS: 86 DAYS}

The facilities analysis takes place in three stages: DOE technical review, tenant technical review, and negotiations of modifications. The DOE technical review is performed by the Managing \& Operating (M\&O) contractor utilizing its unique knowledge of the facility and federal regulatory requirements. The tenant technical review is a tenant-specific, commercial feasibility study. The commercial feasibility study is funded by the CROET or tenant to determine activities and cost associated with transfer of the property from government to private use. The study includes identifying compliance with local and state building codes and is usually conducted by a local Architecture and Engineering firm familiar with local codes and regulations.

\footnotetext{
${ }^{1}$ U.S. DOE Curtis Report, August 24, 1994 Guidance for Support of Local Economic Development Activities establishes the role and responsibilities of the Community Reuse Organization of East Tennessee.
} 


\section{IIA. DOE Technical Review: 86 Days}

The formal request for space by the CROET initiates a process whereby DOE-OR requests (of its Site Office) a technical review of the space for reuse. The technical review is an indepth analysis of the suitability of the candidate facilities for lease.

3. Technical review authorization: 2 days: DOE-OR.

DOE-OR authorizes the DOE technical review of the candidate facilities.

4. Site Office tasks LMES: 2 days: DOE Site Office

Site Office tasks LMES to initiate DOE technical review task.

5. DOE technical review task: 15 days: LMES.

LMES performs the DOE technical review of issues for leasing of facilities. The analysis identifies the baseline physical condition of the space to be leased, physical security issues, safety and health issues, space and equipment modification or relocation, costs, and potential conflicts with ongoing mission activities.

6. Facility modification plan and cost estimate: 20 days: DOE-OR, DOE Site Office, LMES, Tenant/Stakeholder.

The technical review generates an action plan for removing the roadblocks to leasing the candidate facility. Work on the facility modification plan can begin as soon as baseline information from the technical review is available. The flow chart assumes that this information is available 20 working days into the review.

7. DOE technical review approval: 6 days: DOE-OR, DOE Site Office.

DOE-OR and DOE Site Office review and approve the LMES technical review and facility modification plan. DOE-OR forwards the DOE technical review to CROET for review and concurrence with the findings.

8. Community review: 5 days: CROET, tenant.

CROET and tenant (if identified) review the DOE technical review, concentrating on issues that will impact the viability of reuse. 
9. Request U.S. Environmental Protection Agency (EPA) approval for release 2 : 44 days: DOE-OR.

DOE-OR, Site Office submits DOE technical review and facility modification plan to the U.S. EPA for approval of lease agreement.

10. Walk through of requested buildings ${ }^{3}: 1$ day: DOE-OR, DOE Site Office, LMES, EPA.

DOE and LMES familiarize EPA with candidate facilities designated for reuse at DOE sites on the Oak Ridge Reservation. Provide information and physical walk through of buildings.

\section{IIB. Tenant Technical Review: 30 Days}

11. Commercial feasibility study: 20 days: Tenant/Stakeholder or CROET.

Tenant or CROET contracts for an independent assessment of the candidate building's condition. Whereas the DOE technical review provides a general analysis of baseline conditions and internal needs or conflicts, the commercial feasibility study is a detailed analysis of the buildings for compliance with external requirements such as commercial codes and standards. The analysis is primarily conducted for the potential tenants and addresses issues such as handicap access and fire codes, licensing requirements, zoning restrictions, etc.

12. Review of commercial feasibility study: 10 days: DOE-OR, DOE Site Office, LMES.

DOE-OR, DOE Site Office, and LMES review the commercial feasibility study in preparation for negotiations with the CROET.

\section{IIC. Negotiate Modifications: 25 Days}

13. Negotiation of facility modifications: 15 days: DOE-OR, DOE Site Office, LMES, CROET, Tenant/Stakeholder.

All parties reconcile findings of DOE technical review and commercial feasibility study. Negotiate revisions to facility modification plan including responsibility for the performance and the cost of the work; agree upon an action plan necessary to complete the leasing activity.

\footnotetext{
${ }^{2}$ Public Law 103-160, National Defense Authorization Act for Fiscal Year 1994, Section 3154. DOE shall consult with the EPA to determine whether the environmental conditions of the property are such that leasing the property, and the terms and conditions of the lease agreement, is consistent with safety and the protection of public health and the environment. The EPA has 60 calendar days to concur on the lease agreement.
}

${ }^{3}$ Experience at other sites demonstrates this action as a critical step for reasonable and timely review by EPA. 
14. Equipment and existing occupant relocation (if any): 22 days: LMES

Equipment can be moved as a safe shut down activity, eliminating impacts on the CROET or new tenant. This can be done after the CROET review and in parallel with negotiation of facility modifications.

15. Revision of facility modification plan: 10 days: LMES.

LMES provides final revisions to the facility modification plan (if any is needed) based upon the negotiations.

\section{EQUIPMENT TRANSFERS: 38 DAYS}

To offset any delay during the equipment transfer stage, an informal list of personal property available for transfer to new tenant or relocation to previous occupant should be provided to the CROET as soon as possible. The list may be identified during the DOE technical review. The list could be unofficial to allow consideration of property that is only tentatively available. This action may assist the community in the successful marketing of the facility for private use. The list must be formalized and negotiated during the equipment transfer process.

16. Tenant identification: continuing: CROET, Tenant

CROET and tenant identify equipment with potential for reuse to offset local economic impact. ${ }^{4}$

17. High Risk Screening: 10 days: DOE-OR, LMES.

All personal property is subject to the DOE High Risk screening process before conveyance to non-DOE internal or external users. The screening process will review the property for export restrictions, proliferation concerns, public and worker health and safety, and environmental issues. ${ }^{s}$

18. Excess screening: 22 days: DOE-OR, DOE Site Office, LMES.

DOE-OR is authorized to make an excess determination for personal property items with an acquisition cost of less than $\$ 5,000$ and identified as Group 1 or Group 2 in the Federal Supply Classification Group. ${ }^{6}$ All other personal property is subject to Departmental screening through the DOE Reportable Excess Automated Property System (REAPS). ${ }^{?}$

${ }^{4}$ Ibid. Section 3155.

${ }^{5}$ U.S. DOE Personal Property Guidance Letter Issue Number 970-1

${ }^{6}$ Ibid.

${ }^{7}$ Ibid. 
- 19. Conflict resolution: 5 days: DOE-OR.

When there is an item which has been identified for both the CROET and DOE program need, the DOE-OR Manager will resolve the competing claims for the equipment. $^{8}$

\section{NEPA ANALYSIS}

In the Oak Ridge facility reuse schedule, the National Environmental Policy Act (NEPA) analysis process would be on the critical path if an individual facility reuse Environmental Analysis (EA) is pursued for each facility requested. However, for example, a K-25 Site Reuse EA may not be on the critical path if completed before needed. Provided certain conditions are met, Categorical Exclusions (CX) may be used while the Reuse EA is ongoing, as well as prior to that time. For example, by initiating a K-25 Site-wide Reuse EA, the environmental analysis process would be done one time for the entire Site. This action would significantly shorten the sublease process for tenants expressing interest in site facilities once the site EA is completed.

The Reuse EA would encourage private industry interest in, for example, the K-25 Site by providing a shortened time frame for decision making, comparable to expectations at private sites. A site-wide programmatic EA for facility reuse of the entire Oak Ridge Reservation is not being recommended, but a programmatic EA for K-25 Site facility reuse is underway. This is being done since issues involving Y-12 or Oak Ridge National Laboratory (ORNL) reuse alternatives may unnecessarily delay proposed actions for $\mathrm{K}-25$, and, further, those alternatives are not presently available for analysis. Each major unit (K-25, Y-12, ORNL) will be addressed separately. This report provides a standard for all ORR sites, as appropriate.

20. NEPA checklist: 10 days: LMES.

The NEPA checklist is an internal tool to aid DOE-OR and DOE Site Office in determining the necessary level of NEPA review.

IVA. Appendix A7 CX Determination: 2 Days

This subsection identifies the necessary steps if the NEPA checklist recommends an A7 CX for the proposed action.

21.a Approved by DOE Site Office: 1 day: DOE Site Office

22.a Appendix A7 CX determination issued to file by DOE Site Office Environmental Management Division: 1 day: LMES

${ }^{8}$ Ibid. 


\section{IVB. Proposed Appendix B 1.24 CX Determination: 11 Days}

This subsection identifies the necessary steps if the NEPA checklist recommends an Appendix B 1.24 CX for the proposed action (this CX is in the proposal stage and is not yet promulgated as a regulatory alternative).

21.b Approved by DOE Site Office: 1 day: DOE Site Office

22.b Approved by DOE-OR: 10 days: DOE-OR

\section{IVC. Single Facility Environmental Assessment: 117 Days}

This subsection tracks necessary activities if the NEPA checklist recommends an EA.

21c. Approved by DOE Site Office: 3 days: DOE Site Office.

22c. Approved by Site Office: 10 days: DOE Site Office.

23c. Field Study, prepare draft: 63 days: DOE Site Office or designated preparer.

LMES conducts field study and prepares a draft EA.

24c. Pre-approval review Draft to the State and interested members of the public: 31 days: DOE Site Office.

Draft EA is provided to for review and comment.

25c. Comment resolution: 5 days: DOE Site Office or designated preparer.

26c. Approval of EA: 5 days: DOE-OR and Site Office.

\section{IVD. National Historic Preservation Act (NHPA) Process}

\section{1d. Compile NHPA documentation: 2 days: LMES}

In the Oak Ridge facility reuse schedule time line, the NHPA documentation process may be on the critical path if documentation is prepared for each individual facility proposed for lease or transfer. However, a site-wide NHPA document could alleviate many of these time pressures. This action would shorten the sublease process significantly.

22d. Request NHPA consultation: 10 days: DOE-OR

DOE-OR can internally approve for a non-historic structure 
23d. Review and approve Memorandum of Agreement (MOA): 60 days: State Historic Preservation Officer (SHPO), Advisory Council on Historic Preservation (ACHP)

A site-wide MOA would eliminate private sector concerns regarding delays associated with NHPA compliance. Considering for example, the entire K-25 Site at once would also afford opportunities to evaluate reuse, a desired scenario under NHPA, as well as possibilities for some preservation of site artifacts and components with historic significance.

\section{LEASE CONTRACT PREPARATION (Prime Lease): 33 DAYS}

In an effort to streamline management of the lease process, it is suggested that DOE lease management responsibility end with the prime lease execution. With the suggested change, DOE-OR approves the prime lease, allowing the sublease to be executed without DOE review. The level of site involvement should be substantially reduced at the sublease level by transferring sublease management responsibility to the CROET. Sublease authority will allow the CROET the opportunity to make competitive choices between commercial tenants in a timely manner. DOE's interests will be protected through conditions in the prime lease.

Another way to reduce time is to combine all potentially available space for community reuse into one prime lease, signed in advance of individual tenant need. This action, combined with a reuse EA, would allow completion of a subtenant leasing process with only nominal involvement of DOE-OR or Site Office and LMES, reducing the entire process to less than 120 days.

27. Draft lease terms: 10 days: DOE-OR, Site Office, and LMES.

DOE-OR drafts specific terms and conditions of the lease. Terms include general maintenance obligation, insurance, condition of property, existing and future easements and rights of way, termination by government, damage or destruction, surrender, restoration of property, installation, alterations, removal, allocation of liability, utilities and services, liens, access, state and local taxes.

28. Review, negotiate and approve: 22 days: DOE-OR, LMES, CROET, Tenant.

Lease terms are reviewed by all parties. Changes are negotiated and resolved.

Final inventory list accompanies transfer documents by which DOE-OR provides equipment to community. ${ }^{9}$

${ }^{9}$ Tbid. 
29. Lease signing: 1 day: DOE, CROET.

Official signing of the prime lease.

\section{FINAL OCCUPANCY}

30. Build out (if any): undetermined duration: LMES, CROET.

Includes any negotiated alterations contained in the prime lease. Duration of the project determined by build out activities. 
APPENDIX A 
Facility Reuse F Environmental Assessment

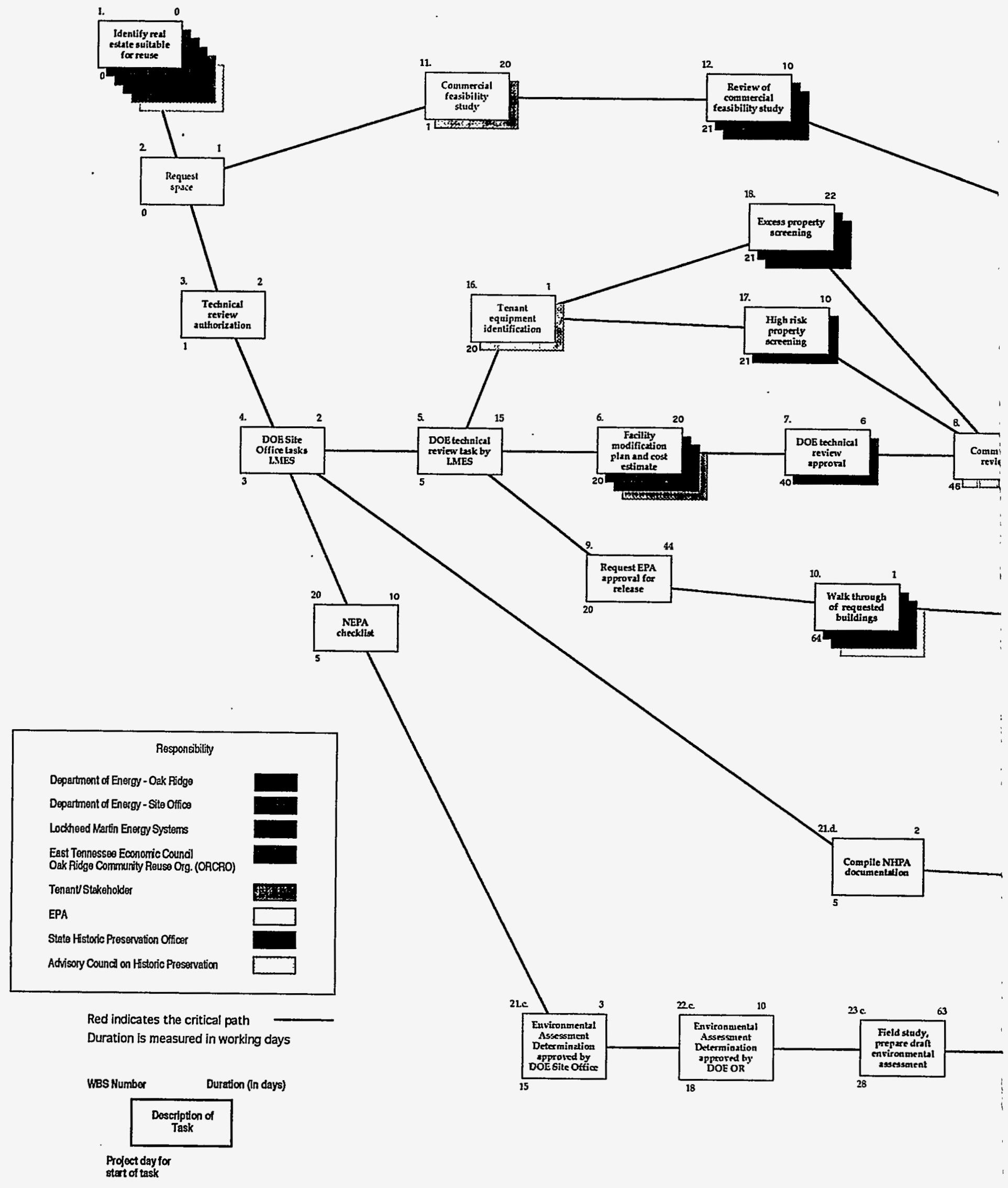




\section{lowchart}

f for a Single Facility

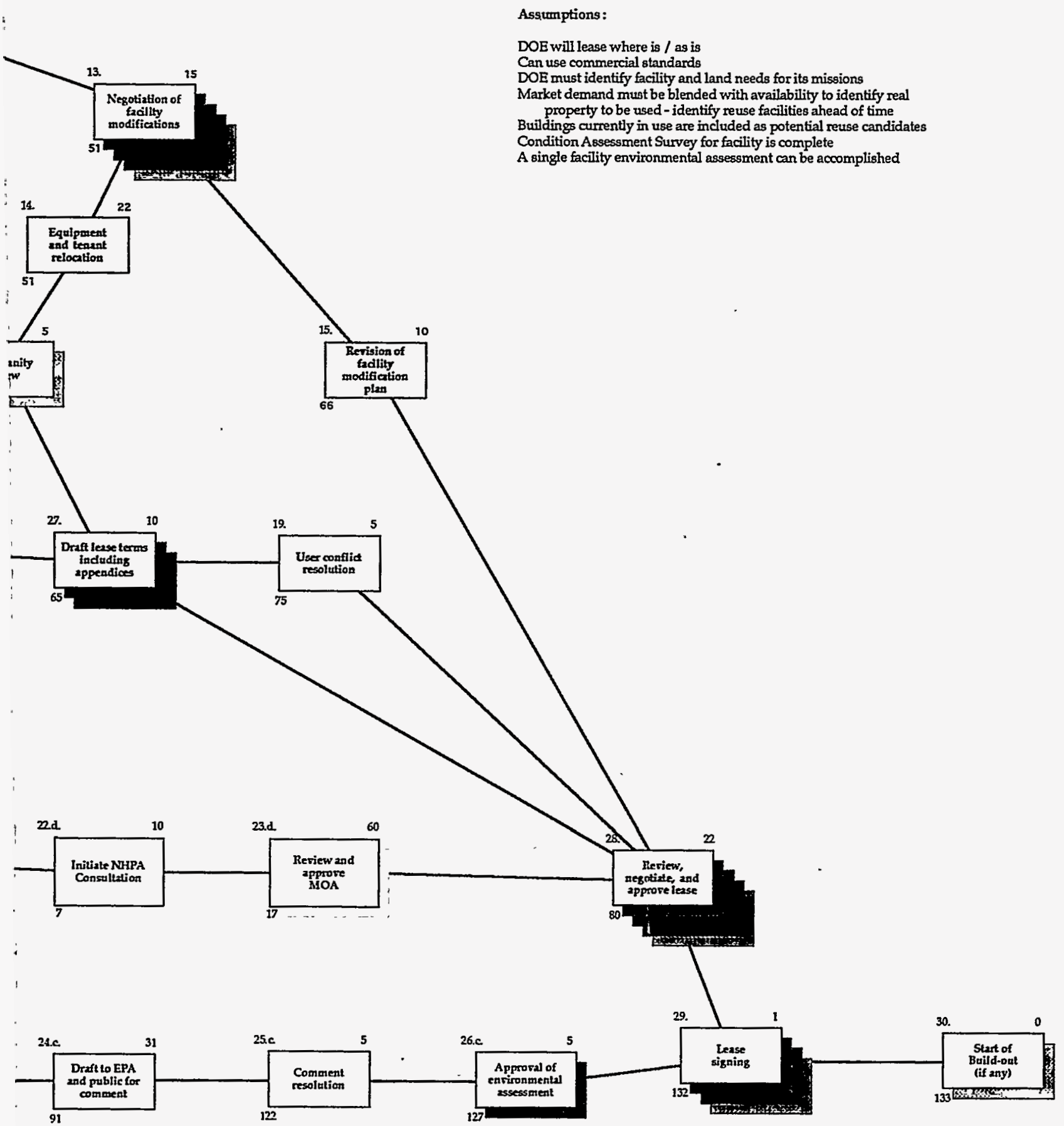




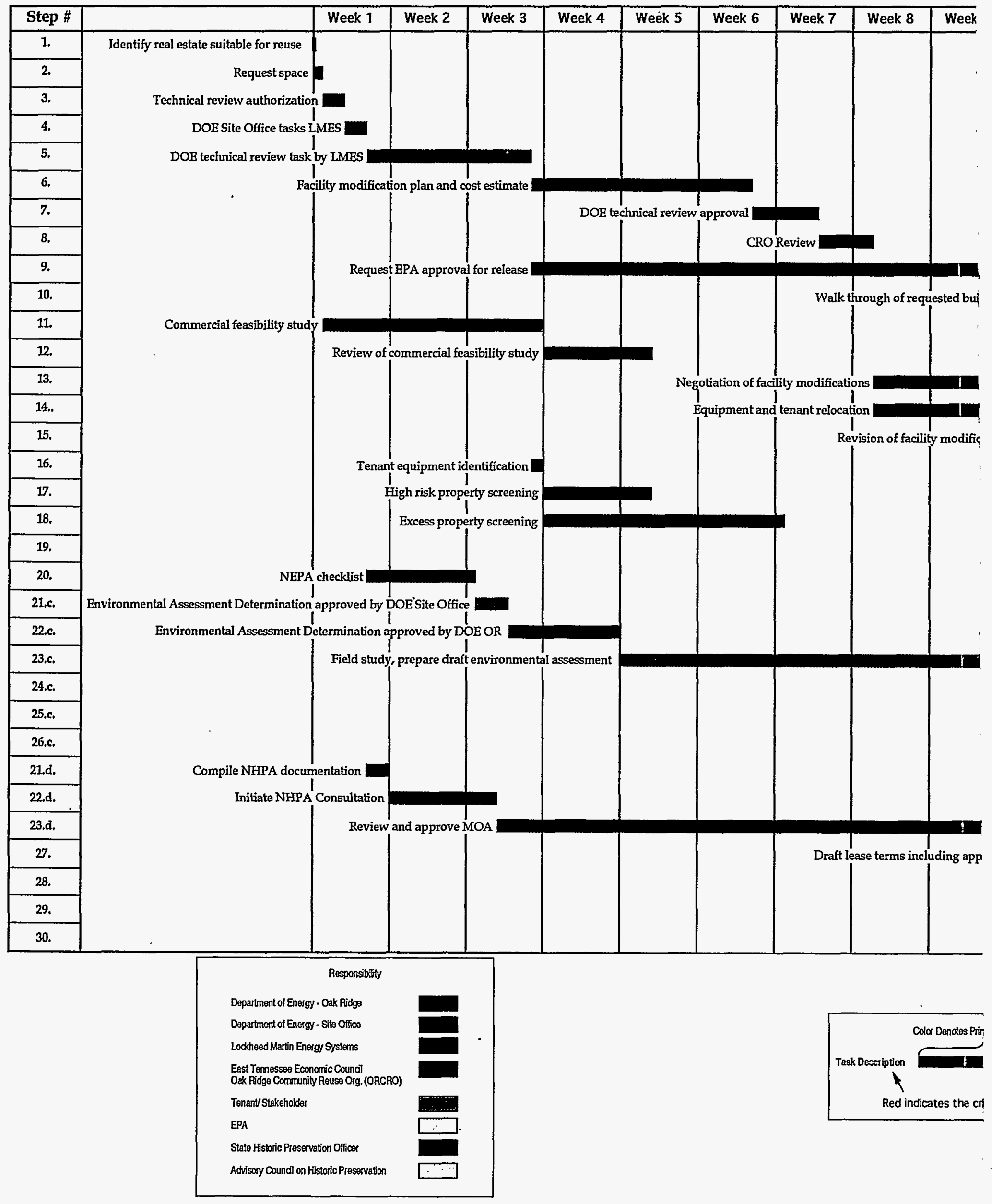


Facility Reuse Fl

Appendix A7 Categorical Excl

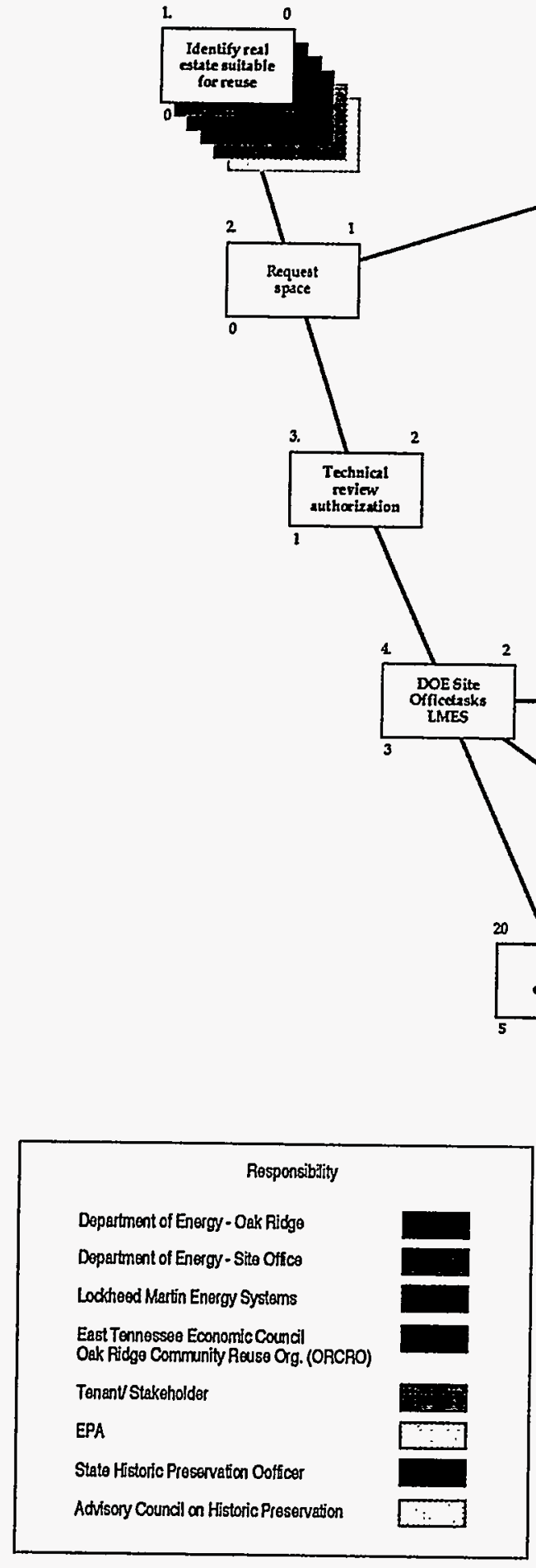

Red indicates the critical path Duration is measured in working days

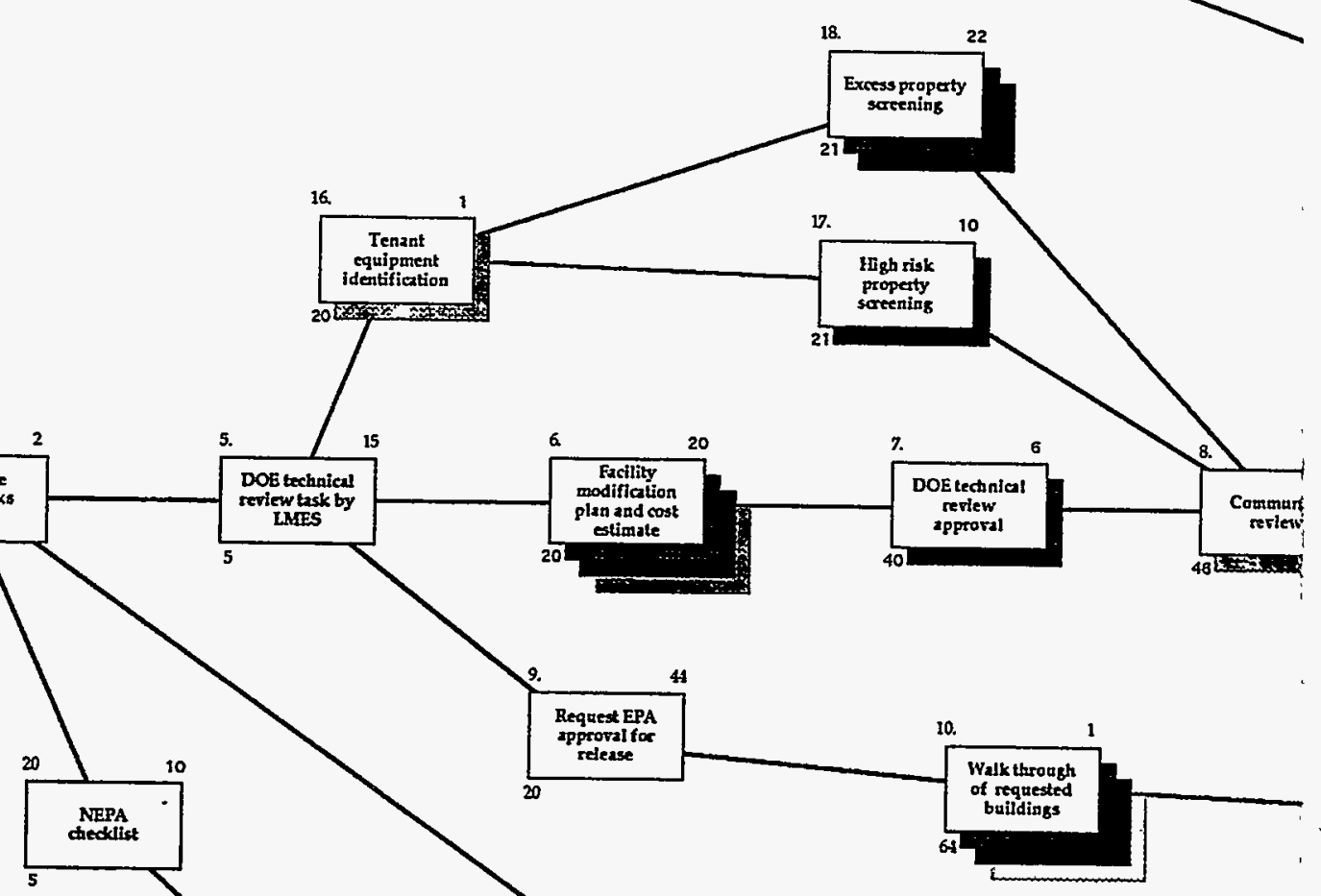




\section{owchart}

usion Is Applicable

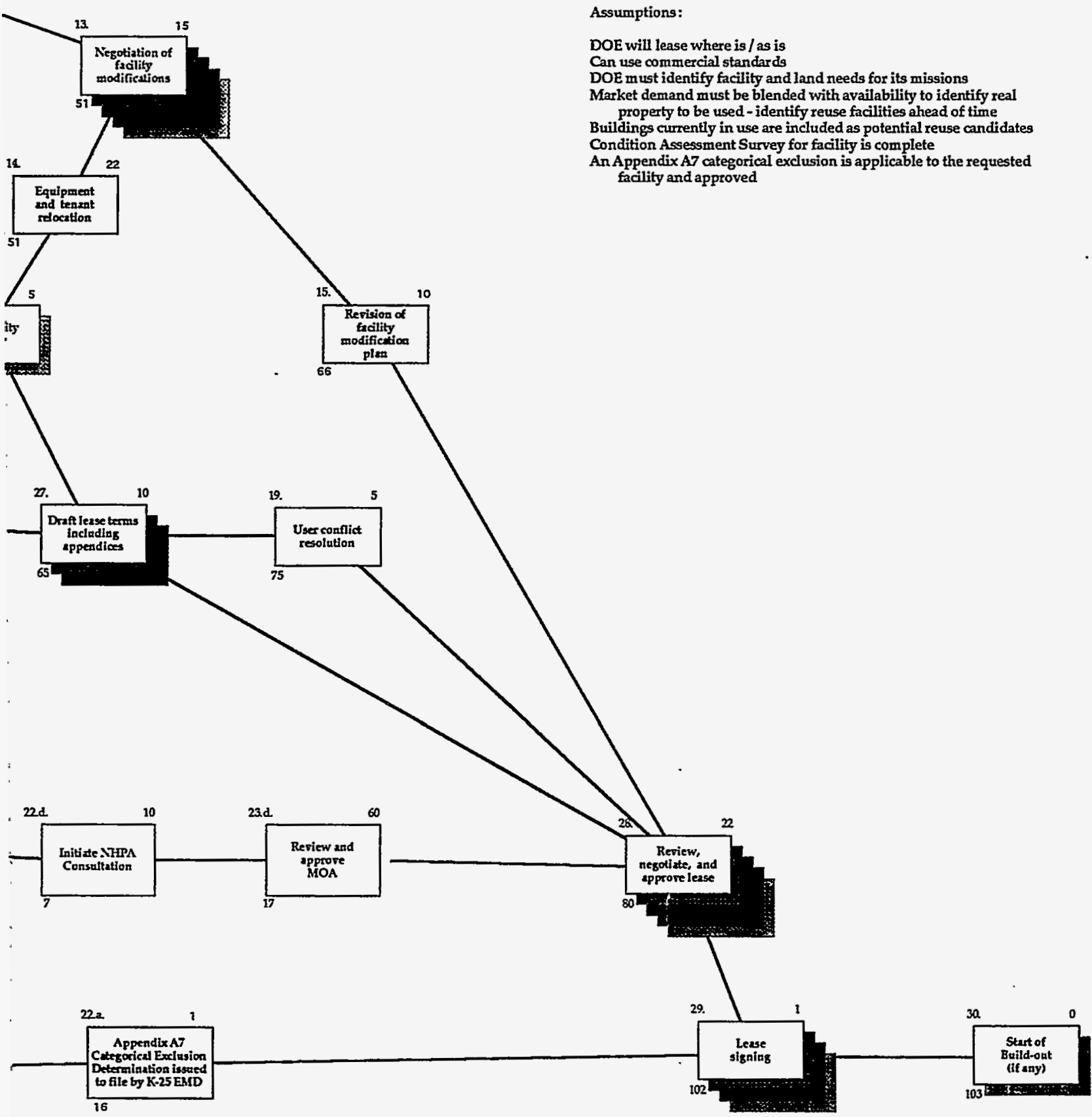


Facility Reuse Tir Appendix A7 Categorical Exclu.

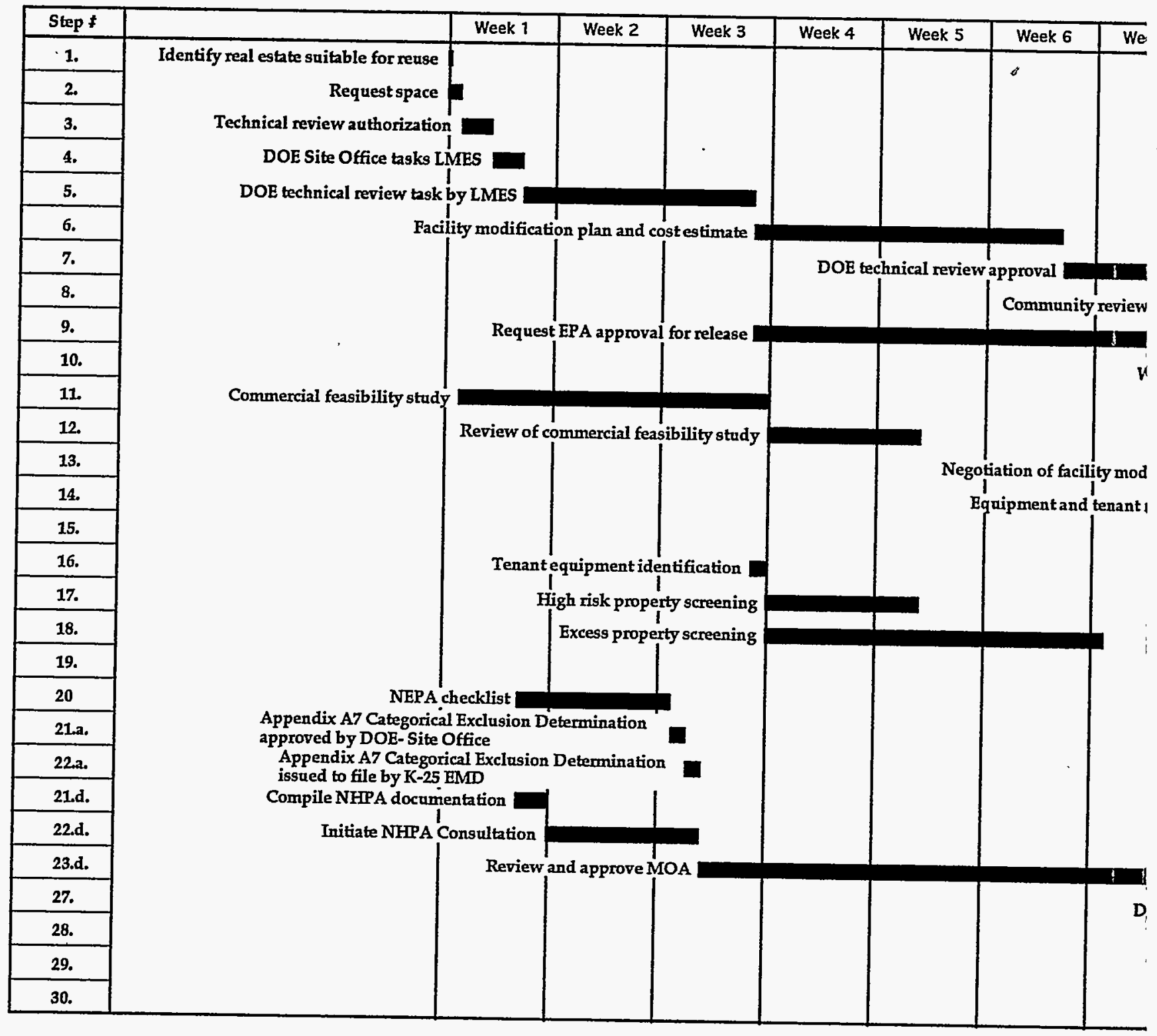

Responsibitity

Deparment of Energy - Oak Fidigo

Department of Energy - Site Offico

Lockhood Martin Enorgy Systoms

East Tennesse日 Economic Counca

Oak Fidge Commanity Reuso Org. (ORCRO)

Tenant/Stakeholder

EPA

Stata Historic Preservation Oofficor

Advisory Council on Historic Preservation
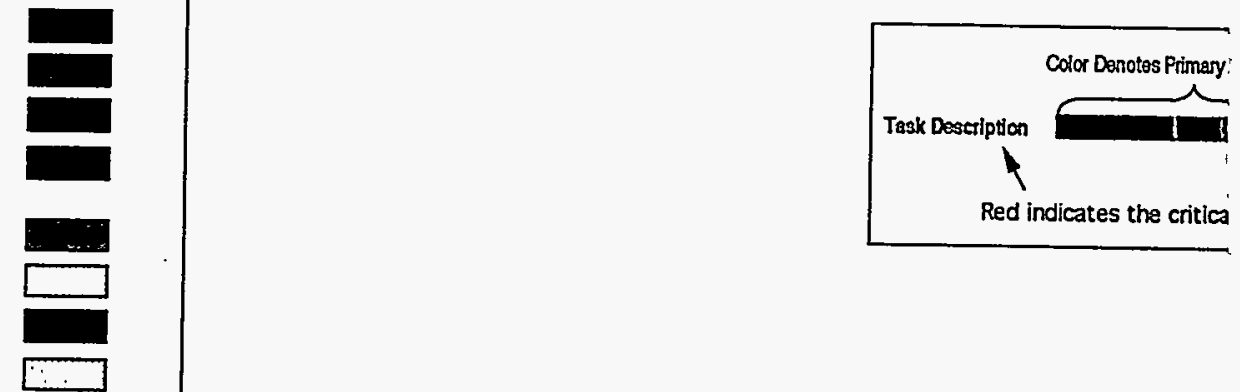


\section{neline}

sion Is Applicable

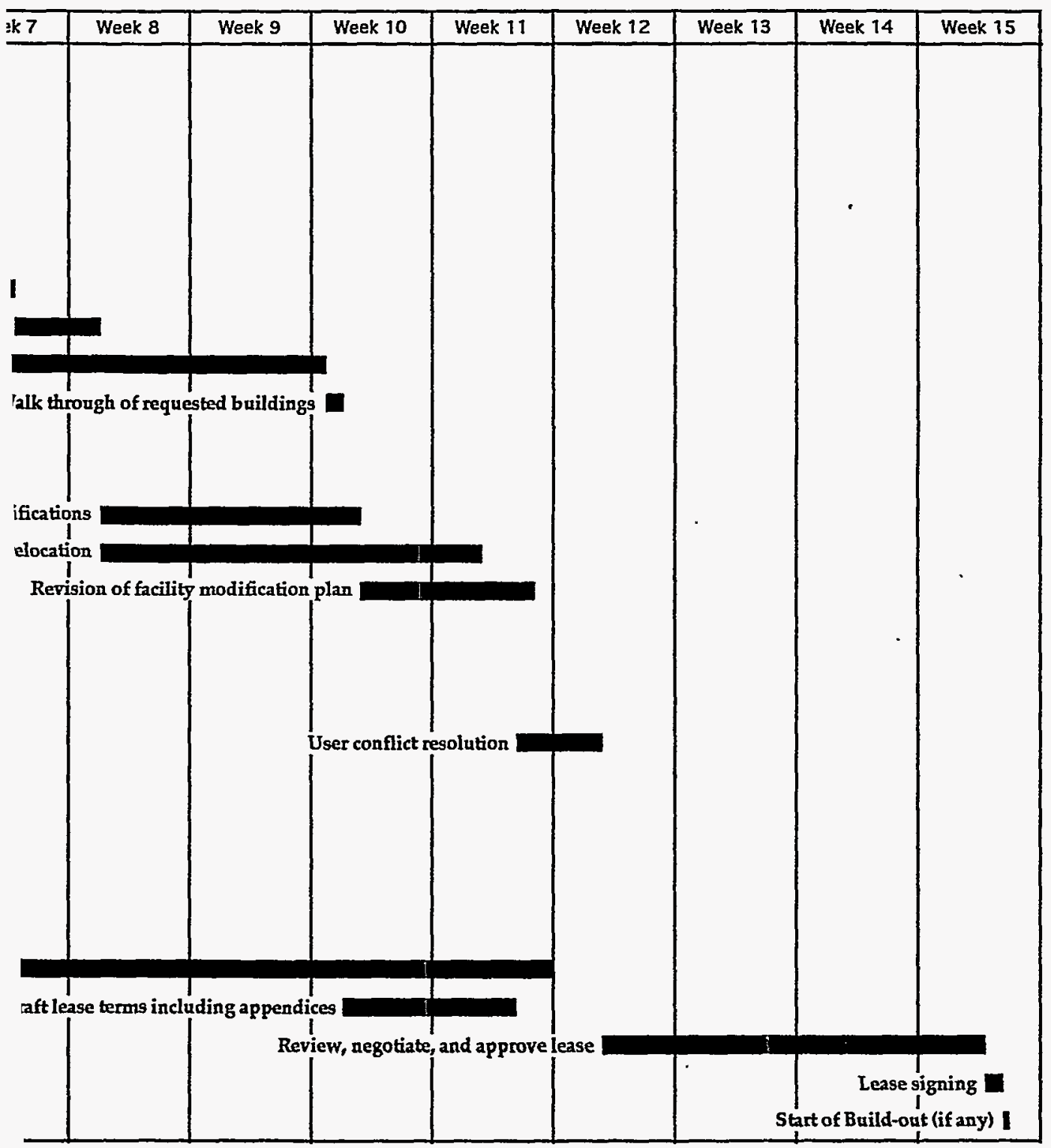

Zosponstitiy

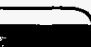

I path
Assimptions:

DOE will lease where is / as is Can use commercial standards

DOE must identify facility and land reeds for its missions Market demand must be blended with availability to identify real property to be used - identify reuse facilities ahead of time Buildings currently in use are included as potential teuse candidates Condition Assessment Survey for facility is complete

An Appendix A categorical exclusion is applicable to the requested facility and approved 


\section{APPENDIX B}




\section{SHORTENING THE CRITICAL PATH}

\section{Background}

An approximately 26 -week process has been proposed for reuse in Oak Ridge. The process begins the day a tenant identifies the necessary space for reuse. At other DOE sites, several activities in the 26-week process have been completed in advance of tenant identification of space and in Oak Ridge one case resulted in the lease of space and equipment under a CX scenario with all work through completed so that lease negotiations were completed in a fiveweek time frame. Circumstances at different sites may make this more or less feasible, but it is presented as an example of an opportunity to shorten the critical path, thereby making the CROET more responsive to the private market demands for timely action.

\section{Reuse EA}

One effort that saves significant time at some sites is a decision to identify space that is likely to be available for reuse in advance of a specific tenant, and then to combine all that space into an environmental analysis (usually an Environmental Assessment) that deals with the range of reasonable reuse activities in advance of the actual subleasing to a specific tenant. Because the environmental analysis process is often one of the longer lead time items for leasing actions, this can save considerable time at the point a tenant comes to the site. Even though the exact use is unknown and there may be follow-up work at the time a tenant is identified, it usually means that the work at that time is insignificant in terms of the time flow to complete a sublease. Further, identification and determination of the property as suitable for reuse are the essential steps. The details of the future user's operations are viewed as being within the realm of the private sector, a matter of independent state and federal regulatory approvals, and outside of DOE's National Environmental Policy Act (NEPA) purview. Waiting until the tenant is identified, the environmental analysis will be on the critical path. Furthermore, the best way to reduce overall time frames is to treat K-25, Y-12, and Oak Ridge National Laboratory as separate sites for reuse. The rationale is that the reuse plans and the continued missions are so diverse at the three locations that it is unrealistic to view them as one site.

\section{Sign the Prime Lease with DOE before Tenant Identification}

Identifying all available space that may be leased to the CROET, then leasing that space in advance of identification by a specific tenant is a way to reduce the lead time to place tenants in possession. This both eliminates the time for prime lease negotiation and allows advanced facility modification needed to accommodate the DOE or its operating contractor. There are two major concerns that typically occur when this is suggested. The issues and suggestions for dealing with them are discussed in the following paragraphs: 
A. Rental costs until a tenant is identified. DOE has nothing to lose by retaining responsibility for maintenance while the CROET tries to find a tenant or tenants for the space. In fact, the CROET has shortened the time between tenant identification and sublease, the point where the CROET would typically assume responsibility for maintenance.

B. DOE control of the subtenants and use of the property. The purpose of the CROET process is to eliminate DOE involvement in the tenant selection process, picking the "winners and losers." Involvement in tenant selection, as a general principal, should be left to the CROET. Nonetheless, DOE has a concern, as owner of the property, that subtenants are responsible and appropriate for the environment in which they will be working. This can be managed by establishing an acceptable range of tenants and uses in writing of the prime lease. This avoids the necessity to involve DOE or LMES in the sublease process, an advantage to DOE and the CROET.

\section{Notice of Opportunity}

Fairness of opportunity is a major issue from DOE's perspective and was dealt with in the published guidelines for reuse of DOE facilities. One way to assure faimess is to advertise the opportunity early and with a broad distribution. Industry days or similar activities that encourage firms to tour the site and see what might be available also are of value. The bottom line is that some announcement in local and national publications "puts the world on notice" and satisfies the DOE requirement for fairness of opportunity.

\section{Early Identification of Equipment}

Cooperative efforts to identify equipment potentially available for community reuse is a step that can save time if DOE is willing to do early screening. It can also be part of the attraction to tenants, thereby becoming a marketing tool for the CROET. This should be explored with DOE and LMES to see if it is possible at the site. There is a down-side risk that needs to be understood. The screening may identify off-site interest before the CROET has a well defined need for the equipment. For this reason, some sites have been reluctant to do anything other than to allow the CRO to physically inspect the facilities and identify the items they judge to be of potential interest to potential tenants.

\section{Combined National Historic Preservation Act (NHPA) Documentation}

Compliance with the NHPA, for example, for the K-25 Site, could take a great deal of time on a repetitive basis if NHPA documentation is prepared for individual facility leases. A time-saving way to proceed would be to prepare a site-wide Memorandum of Agreement (MOA) as part of the Reuse EA, or a stand-alone MOA for the Site. This will reduce individual facility documentation requirements from several months to several weeks. 
Facility Reuse Flor

Appendix B 1.24 Categorical Excl

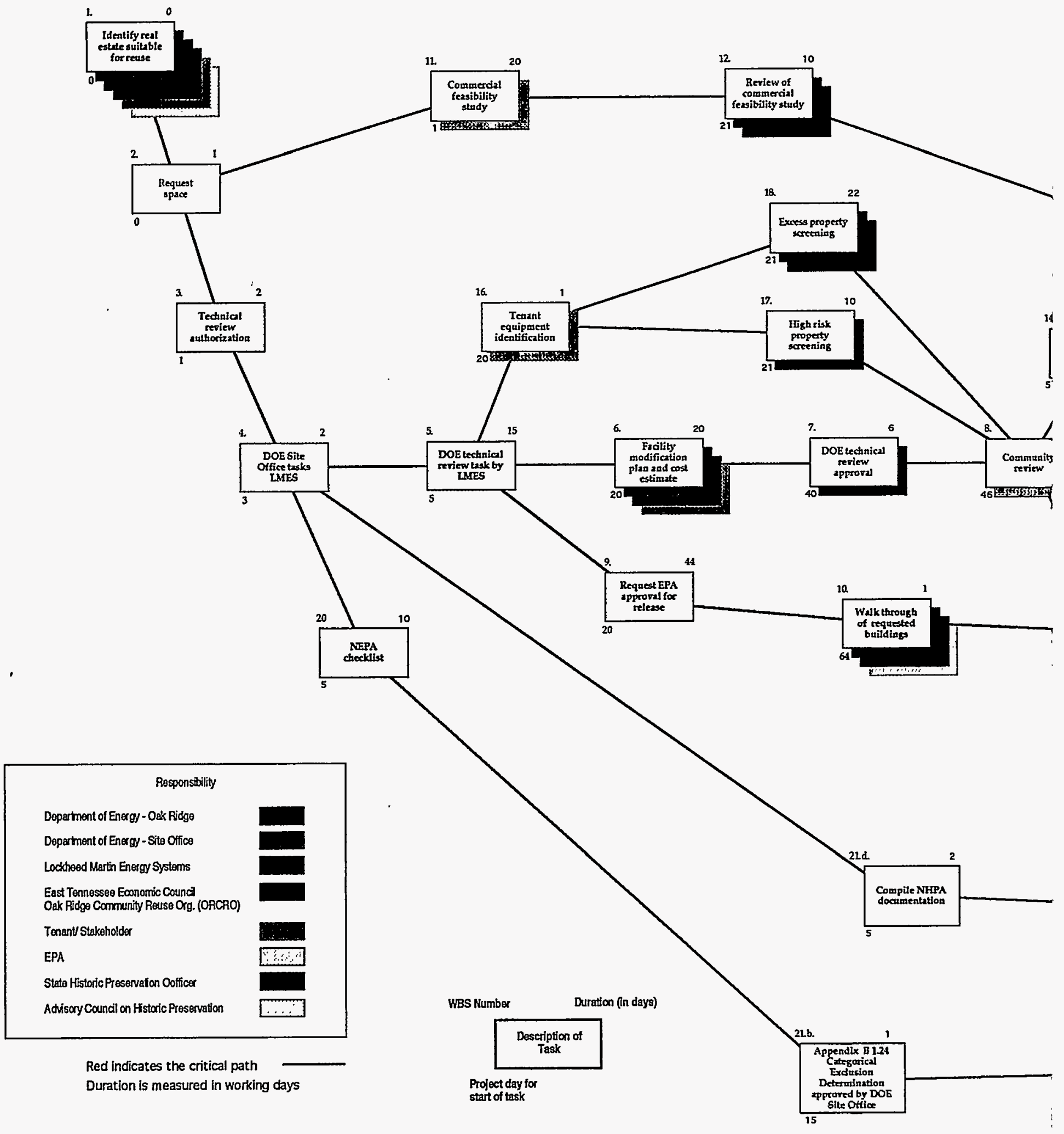


wchart

usion Is Applicable

Assumptions :

DOE will lease where is / as is

Can use commercial standards

DOE must identify facility and land needs for its missions

Market demand must be blended with availability to identify real

property to be used-identify reuse facilities ahead of time

Buildings currently in use are included as potential reuse candidates

Condition Assessment Survey for facility is complete

An Appendix B 1.24 categorical exclusion is applicable to the requested facility and approved

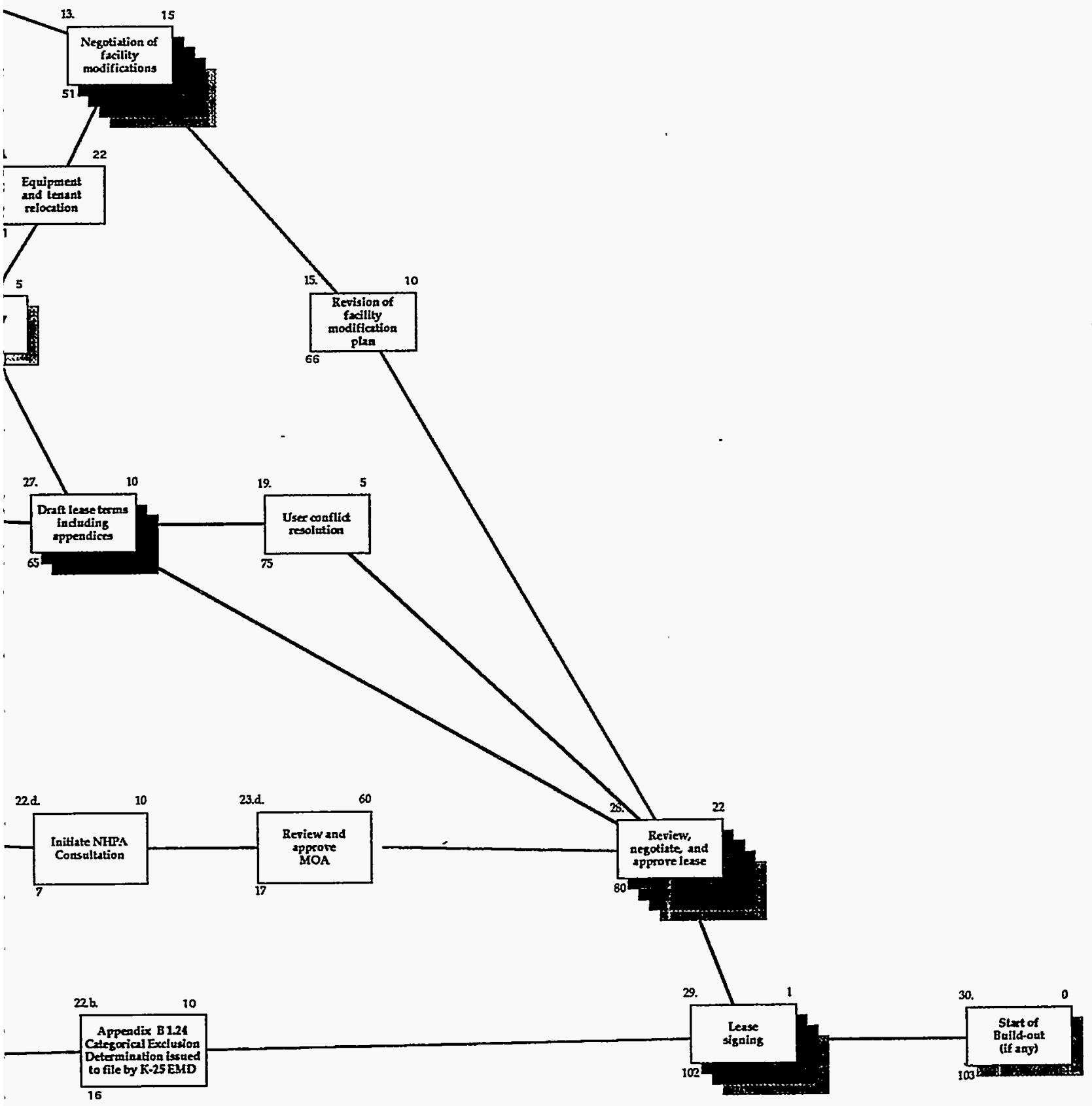


Facility Reuse T

Appendix B 1.24 Categorical E:

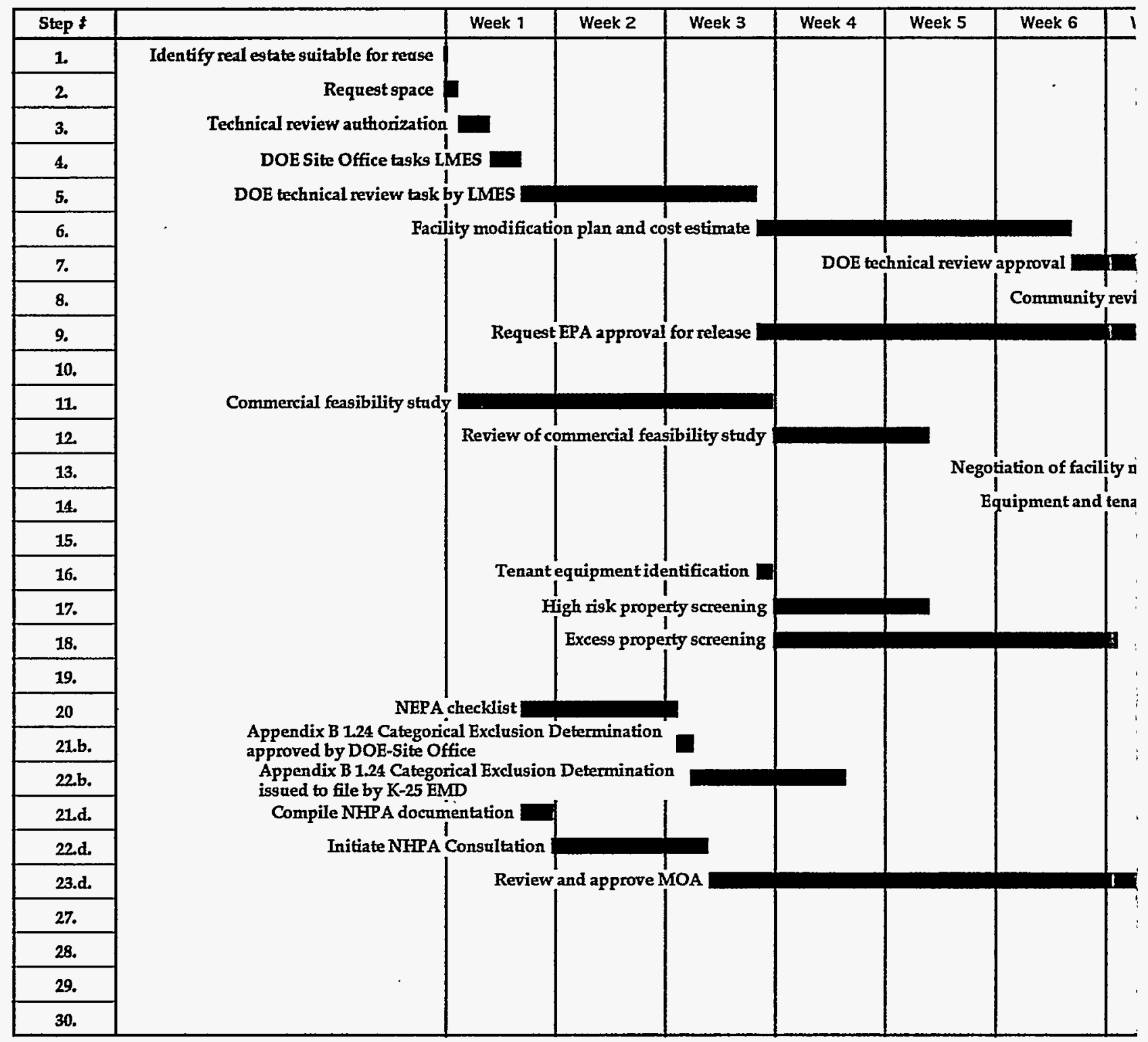

Responsibitity

Deparment of Energy - Oak Ridge

Department of Energy - Site Office

Lockheed Martin Energy Systoms

Eest Tennessea Economic Counc: Oak Ridge Community Reuse Org. (ORCRO)

Tenant/Stakehoider

EPA

State Historic Preservation Ooficer

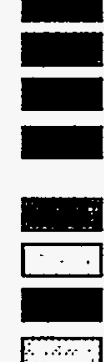

Color Denotes Prir

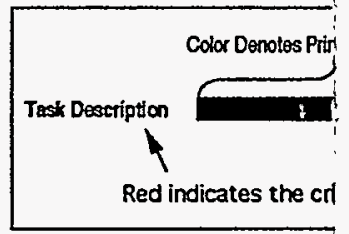

Advisory Counci on Historic Preservation 


\section{DISTRIBUTION}

\section{Internal}

$\begin{array}{lll}\text { Bates, L. D. } & \text { Gustavson, F. P. } & \text { Morris, T. W. } \\ \text { Beck, D. E. } & \text { Hall, L. E. } & \text { Mynatt, C. M. } \\ \text { Bingham, C. A. } & \text { Hart, T. E. } & \text { Neff, R. A. } \\ \text { Bostock, D. J. } & \text { Hemenway, J. M. } & \text { Newman, J. R. } \\ \text { Bowdle, K. K. } & \text { Herron, S. A. } & \text { Overly, J. B. } \\ \text { Bunchman, R. H. } & \text { Herron, A. N. } & \text { Owens, N. C. } \\ \text { Clinard, J. A. } & \text { Humphrys, W. T. } & \text { Person, G. } \\ \text { Conner, H. T., Jr. } & \text { Jacks, M. M. } & \text { Rackstraw, A. L., Jr. } \\ \text { Crothers, H. L., Jr. } & \text { Kendall, D. T. } & \text { Taylor, T. D. } \\ \text { Cusick, L. T. } & \text { Kingrea, R. H. } & \text { Teer, W. W. Jr. } \\ \text { Davis, S. M. } & \text { Koger, J. W. } & \text { Thompson, J. E. } \\ \text { DeLozier, M. F. P. } & \text { Loebl, A. S. (20) } & \text { Thompson, W. W., Jr. } \\ \text { Donnelly, R. G. } & \text { Lowe, S. H. } & \text { Van Dyke, R. H. } \\ \text { Eaker, D. S. } & \text { Malinauskas, A. P. } & \text { Vaughn, B. E. } \\ \text { Fellows, R. L. } & \text { Manly, W. D. } & \text { White, D. } \\ \text { Fleenor, R. M. } & \text { Mason, D. L. } & \text { White, R. K. } \\ \text { Genung, R. K. } & \text { Massey, J. C. } & \text { Whitten, M. L. } \\ \text { Goins, C. D. } & \text { Morello, J. J., Jr. } & \text { Worrell, R. D. } \\ \text { Guilford, J. S. } & & \\ & & \end{array}$

\section{U. S. Department of Energy}

Carnes, N. L. (DOE-ORO)

Clark, L. W. (DOE-ORO)

Copeland, M. D. (DOE-ORO)

Frounfelker, R. E. (DOE-ORO)
Kates, K. (DOE-ORO)

Patrick, E. J. (DOE-ORO)

Roettger, M. H. (DOE-ORO)

Walker, B. D. (DOE-ORO)

\section{External}

Caldwell, C. W. (SAIC)

Canestaro, J. C. (BWS\&C)

Disse, T. (RRI)

Lenhard, J. A. (CROET)
Scott, B. C. (RRI)

Sullivan, R. G. (RRI)

Trost, D. G. (SAIC)

Young, L. T. (CROET) 